Abstracta Iranica Abstracta Iranica

Revue bibliographique pour le domaine irano-aryen

Volume 29 | 2008

Comptes rendus des publications de 2006

\title{
« Trade routes to Hatra according to evidence from ancient sources and modern satellite imagery $»$. Baghdader Mitteilungen, 35, 2004, pp. 59-86.
}

\section{Vito Messina}

\section{(2) OpenEdition}

Journals

Édition électronique

URL : http://journals.openedition.org/abstractairanica/26542

DOI : 10.4000/abstractairanica.26542

ISSN : 1961-960X

Éditeur :

CNRS (UMR 7528 Mondes iraniens et indiens), Éditions de l'IFRI

Édition imprimée

Date de publication : 15 mai 2008

ISSN : 0240-8910

Référence électronique

Vito Messina, « «Trade routes to Hatra according to evidence from ancient sources and modern satellite imagery ». Baghdader Mitteilungen, 35, 2004, pp. 59-86. », Abstracta Iranica [En ligne], Volume 29 | 2008, document 100, mis en ligne le 15 septembre 2008, consulté le 26 septembre 2020. URL : http://journals.openedition.org/abstractairanica/26542 ; DOI : https://doi.org/10.4000/ abstractairanica.26542

Ce document a été généré automatiquement le 26 septembre 2020.

Tous droits réservés 


\title{
« Trade routes to Hatra according to evidence from ancient sources and modern satellite imagery $»$. Baghdader Mitteilungen, 35, 2004, pp. 59-86.
}

\author{
Vito Messina
}

Even if the city of Hatra is well known as a political and religious centre of Eastern Jazirah, its role in long distance trade-routes still remains enigmatic. This article focuses on the major routes leading towards the city, comparing the study of modern satellite imagery with a further reading of ancient sources, in particular the so-called Tabula Peutingeriana. This Roman itinerary map points out the city of Hatra as a pivot in ancient trade-routes, connecting lowland Mesopotamia with the eastern border of the Roman Empire. Satellite imagery allows the Authors to verify the course of the routes described in the map, supporting the evidence that these - as shown in the tabula bypassed Assur. Furthermore, the comparison between the map and satellite images contributes to the understanding of the city's development from a nomadic level to a high-rank political capital.

\section{INDEX}

Thèmes : 3.2.3. Séleucides, Parthes et Sassanides 
AUTEURS

VITO MESSINA

Università di Torino 